\title{
Components of airway disease
}

To the Editors:

"What we think we know already often prevents us from learning" (Claude Bernard)

I endorse the view of HARGREAVE and PARAMESWARAN [1] that the components of airway disease, inflammation (bronchitis), reversibility (asthma), and chronic airflow limitation (chronic obstructive pulmonary disease (COPD)), are not "mutually exclusive and [...] commonly occur together." I would like to mention further evidence in support of their position.

I would add the longitudinal (natural history) perspectives of the primary-care practitioner [2] and the epidemiologist [3]. Clinical reports from primary care document that acute bronchitis can precede asthma, which then develops into severe COPD over a few years [4] to decades [2]. Perhaps the best longitudinal evidence derives from a cluster-randomised, population-based 20-yr prospective study finding that asthma was the strongest risk factor for subsequent COPD, both in relative (hazard ratio $(\mathrm{HR})=12.5$ ) and absolute (attributable risk $(\mathrm{AR})=18.5 \%$ ) terms compared with tobacco smoking $(\mathrm{HR}=2.9$ for current smoking, $\mathrm{AR}=6.7 \%$ for ever-smoking) [3].

The dogma that asthma and COPD are different diseases (and therefore should be studied separately) appears to have been derived from the mainly cross-sectional perspectives of academic referral lung specialists (adult and paediatric allergists, pulmonologists) who for the most part have not had the opportunity to observe the natural history of lung disease over a patient's lifetime. I can think of no better explanation for a recent statement by a prominent leader in lung research: "Chronic obstructive pulmonary disease is probably the only chronic disease for which the finger of blame can be pointed at a single risk factor - tobacco smoking" [5].

\section{D.L. Hahn}

Dean Medical Center, Madison, Wisconsin, USA.

\section{REFERENCES}

1 Hargreave FE, Parameswaran K. Asthma, COPD and bronchitis are just components of airway disease. Eur Respir J 2006; 28: 264-267.

2 Hahn DL. Evaluation and management of acute bronchitis. In: Hueston WJ, ed. 20 Common Problems in Respiratory Disorders. New York, McGraw-Hill, 2002; pp. 141-153.

3 Silva GE, Sherrill DL, Guerra S, Barbee RA. Asthma as a risk factor for COPD in a longitudinal study. Chest 2004; 126: 59-65.

4 Hahn D, Bukstein D, Luskin A, Zeitz H. Evidence for Chlamydia pneumoniae infection in steroid-dependent asthma. Ann Allergy Asthma Immunol 1998; 80: 45-49.

5 Hurd SS, Lenfant C. COPD: good lung health is the key. Lancet 2005; 366: 1832-1834.

\section{Three new cases of apparent occupational asthma in swine confinement facility employees}

\section{To the Editors:}

In a previous issue of the European Respiratory Journal, DOSMAN et al. [1] reported on four cases of occupational asthma in newly employed workers in the large, recently developed, swine production facilities in Saskatchewan (Canada). All were full-time employees and all developed symptoms suggestive of asthma within a short time of commencing employment. None of the cases had a history of asthma, allergy symptoms or previous exposure to indoor air contaminants of swine confinement facilities. Work in swine buildings has been associated with respiratory symptoms, reductions in mean and across-shift lung function values [2], and increased bronchial responsiveness [3, 4]. Asthma has been reported in swine workers, but this has typically occurred in workers with lengthy employment $[5,6]$.

Cases 1-3 in our initial report showed some reaction to skinprick allergy tests. While forced expiratory volume in one second (FEV1) for case 1 was relatively stable over time, provocation challenge causing a $20 \%$ fall in FEV1 (PC20) was reduced for several months following resignation from the swine barn. Case 1 also experienced symptoms requiring removal from the barn during a re-entry challenge. It was speculated that these cases might exhibit a type of occupational asthma, described by BROOKS et al. [7], as "not-so-sudden onset" nonallergic asthma resulting from irritant exposure over a number of months.

Since the initial study [1], we have encountered three additional cases that have been labelled as cases 5, 6 and 7 (table 1). In contrast to the previous four cases, the cases reported herein are all male. Again, none of the cases had a history of asthma or wheeze and none had reported previous regular occupational exposures in a swine confinement facility. Each of the cases developed symptoms within weeks to months of commencing employment and each has had continued sensitivity to exposures in a swine barn. 


\begin{tabular}{|c|c|c|c|}
\hline & Case 5 & Case 6 & Case 7 \\
\hline Occupational exposure time months & 21 & 10 & 12 \\
\hline $\begin{array}{l}\text { Time from onset of work to onset of } \\
\text { symptoms months }\end{array}$ & 6 & Shortly after commencing work & $<1 \mathrm{yr}$ \\
\hline \multirow[t]{3}{*}{ Wheal size $\mathrm{mm}^{\S}$} & Shellfish (1-2) & House dust mite (1-2) & Not completec \\
\hline & House dust (1-2) & & \\
\hline & Grain dust $(>3)$ & & \\
\hline Smoking status & Ex-smoker of $11 \mathrm{yrs}$ & Ex-smoker of $1 \mathrm{yr}$ & Unknown \\
\hline
\end{tabular}

FEV1: forced expiratory volume in one second; PC20: provocative concentration causing a 20\% fall in FEV1. Cases described herein are designated as cases $5,6,7$ to

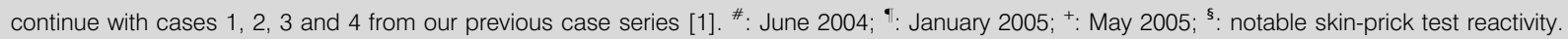

Case 5 was a 48-yr-old ex-smoker who began working in the swine industry in late 2002. Within 6 months of employment, he began to have respiratory symptoms, which eventually led to a severe episode several months after commencement of work. Pulmonary function showed evidence of mild airways obstruction, but a post-bronchodilator test was not conclusive. He underwent methacholine challenge testing where FEV1 decreased by $18 \%$ at $4 \mathrm{mg} \cdot \mathrm{mL}^{-1}$, compatible with a mild increase in airways responsiveness. However, overall PC20 was not calculable because, at $8 \mathrm{mg} \cdot \mathrm{mL}^{-1}$, the decrease in FEV1 was $12 \%$. He exhibited mild skin-prick test reactivity to shellfish and house dust, along with strong reactivity to grain dust. $\mathrm{He}$ improved while away from work but continues to work part time at the swine facility.

Case 6 was a 47-yr-old ex-smoker. He began working in the swine barns in early 2003. Shortly after commencing work, he developed respiratory symptoms, which improved away from work. After $1 \mathrm{yr}$, he resigned from work. FEV1 at the clinic was $3.36 \mathrm{~L}$ while PC20 was $1.95 \mathrm{mg} \cdot \mathrm{mL}^{-1}$. He had a mild skin-prick test reaction to house dust mite. Since resigning, he continues to be bothered by cough and wheeze, as well as continuing to use fluticasone propionate b.i.d. (GlaxoWellcome Inc., Mississauga, ON, Canada).

We have less information for case 7, a 30-yr old who had spent 1 yr working in a swine barn $\sim 10$ yrs ago. He developed cough and wheeze shortly after commencing, which continued after quitting the barn. Allergy skin-prick testing and pulmonary function testing was not completed.

The addition of these new cases to the previous case series [1] leads us to believe that the extent of this condition may be more common than originally suspected, and that some newly employed workers in swine confinement facilities are at risk of developing a form of asthma identified as "not-so-sudden onset asthma" [7]. Pre-employment assessments and frequent early employment monitoring of workers may be important tools in addressing early respiratory effects in workers in this industry. Finally, we believe that studying this population would provide further insight into the mechanisms by which occupational asthma occurs among workers in these facilities.

\section{J.A. Dosman*\#, J.A. Lawson, S.P. Kirychuk, Y. Cormier", J. Biem and N. Koehncke*}

*Institute of Agricultural Rural and Environmental Health (IAREH), and "Dept of Medicine, University of Saskatchewan, Saskatoon, Saskatchewan and "Hopital and Universite Laval, St Foy, Quebec, Canada.

\section{REFERENCES}

1 Dosman JA, Lawson JA, Kirychuk S, Cormier Y, Biem J, Koehncke N. Occupational asthma in newly employed workers in intensive swine confinement facilities. Eur Respir J 2004; 24: 698-702.

2 Zejda J, Hurst T, Rhodes C, Barber E, McDuffie H, Dosman J. Respiratory health of swine producers. Focus on young workers. Chest 1993; 103: 702-709.

3 Malmberg P, Larsson K. Acute exposure to swine dust causes bronchial hyperresponsiveness in healthy subjects. Eur Respir J 1993; 6: 400-404.

4 Bessette L, Boulet L, Tremblay G, Cormier Y. Bronchial responsiveness to methacholine in swine confinement building workers. Arch Environ Health 1993; 48: 73-77.

5 Donham KJ. The concentration of swine production. Effects on swine health, productivity, human health, and the environment. Vet Clin North Am Food Anim Pract 2000; 16: 559-597.

6 Holness DL, Nethercott JR. What actually happens to the farmers? Clinical results of a follow-up study of hog confinement workers. In: McDuffie H, Dosman J, Semchuk KM, Olenchock SA, Senthilselvan A, eds. Agricultural Health and Safety. Workplace, Environment, Sustainability. Boca Raton, CRC Lewis Publishers, 1995; pp. 44-52.

7 Brooks SM, Hammad Y, Richards I, Giovinco-Barbas J, Jenkins K. The spectrum of irritant-induced asthma: sudden and not-so-sudden onset and the role of allergy. Chest 1998; 113: $42-49$. 